\title{
Investigation of the relationship between motor vehicle driver violations, visual search, attention deficit hyperactivity disorder, and age of drivers
}

\author{
Seyed Hojjat Zamani Sani ${ }^{*}{ }^{(\mathbb{D}}$, Zahra Fathirezaie${ }^{1}$, Homayoun Sadeghi-Bazargani², Kosar Abbaspour $^{3}$ \\ 1. Assistant Professor of of Motor Behavior, Motor Behavior Group, Physical Education and Sport Sciences Faculty, University of Tabriz, \\ Tabriz, Iran \\ 2. Road and Traffic Injury Research Center, Tabriz University of Medical Sciences, Tabriz, Iran \\ 3. PhD Student of Motor Behavior, Physical Education and Sport Sciences Faculty, University of Tabriz, Tabriz, Iran
}

Recieved: 13 Dec. 2018

Revised: 17 May 2019

Accepted: 28 May 2019

\section{Keywords \\ Visual search \\ Attention deficit hyperactivity \\ disorder \\ Driving violations}

\section{Corresponding author}

Seyed Hojjat Zamani Sani, Assistant Professor of Motor Behavior, Faculty of Physical Education and Sport Sciences, University of Tabriz, Tabriz, Iran

Email: Hojjatzamani8@gmail.com

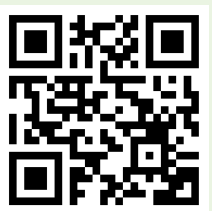

\section{Abstract}

Introduction: The purpose of this research was to study the relationship between visual search, some individual characteristics, and violations of vehicle drivers.

Methods: In this correlational study, 548 subjects aged 18 to 90 years, were selected by cluster sampling method. We used a questionnaire to assess the rate of driving violations and individual characteristics and CogLab software to measure visual search. Also, hyperactivity disorder in individuals was investigated through the Adult ADHD Self-Report Scale. Data were analyzed using Pearson correlation, partial correlation and multivariate regression at a significance level of 0.05 and SPSS-20 software.

Results: The results showed that there was no significant relationship between age some accidents and ADHD. There was a negative and significant relationship between age and self-reporting violations. Furthermore, a high index of ADHD positively related to self-reporting violations. In the following the results of correlation among the number of driving violations with visual search showed a negative and significant relationship among most of the variables. The results of linear regression showed that age negatively and number of accidents, ADHD, lack of conjunctive absent (number of distractors $=4$ ), and feature absent (number of distractors $=64$ ) positively can predict about $28 \%$ of driving violations variance.

Conclusion: As age increases, the amount of self-reported violations is reduced. The positive relationship between ADHD and the total number of accidents and self-reported violations indicates an inadequate ability to attention and focus, low control to conditions, and impulsive behaviors that could lead to this relationship. Also, with decreasing age, as well as the increasing people's visual search ability, the rate of self-reported violations increases. 


\title{
بررسى رابطه بين رفتار هاى رانندكى، جستجوى بينايى، اختلال كم توجهى_بيشفعالى و سن در رانندكان وسايل نقليه سوارى
}

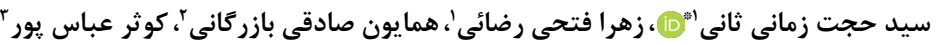

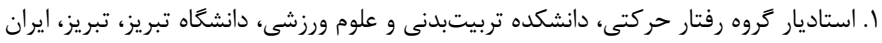

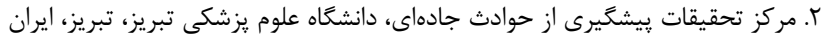

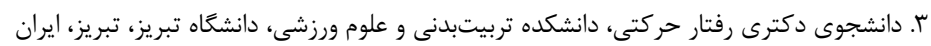

\section{ars}

مقلدمه: مطالعه حاضر به منظور بررسى رابطه بين جستجوى بينايى، برخى ويثگى هاى فردى و تخلفات رانندكان وسايل نقليه سوارى انجام شد. روش كار: در اين يزوهش كه به روش همبستكى انجام شد، هF آزمودنى در رده سنى 1 تا •و سال، به روش نمونه گيرى خوشهاى انتخاب شدند. براى بررسى ميزان تخلفات رانندگى و ويثَى هاى فردى از ״رسشنامه اطلاعات فردى و براى سنجش جستجوى بينايى از نرمافزار CogLab استفاده شد. همجنين اختلال كم توجهى يِيشفعالى افراد، از طريق يرسشنامه خودززارشى اختلال كم توجهى_بيشفعالى بزركسالان مورد بررسى قرار گرفت. تجزيه و تحليل دادها با استفاده از همبستگى پِيرسون، همبستگى جزئى و ركرسيون جند متغيره نرمافزار SPS-20 انجام شد. يافته ها: نتايج نشان داد رابطه معنادارى بين سن با تعداد تصادفها و داشتن اختلال كم توجهى بيشفعالى وجود نداشت. بين سن با تخلفات خودگزارشى، رابطه منفى و معنادار، و بين تعداد كل تصادفها با تخلفات خودگزارشى و داشتن اختلال كم-توجهى مِيشفعالى رابطه مثبت و معنادارى مشاهده شد. نتايج مربوط به همبستخى نشان داد كه بين ميزان تخلفات راندكىى با مؤلفههاى جستجوى بينايى، در اكثر متغيرها، رابطه منفى و معنادارى وجود دارد. نتايج ركرسيون خطى نيز نشان داد كه سن به صورت منفى و تعداد تصادفات، اختلال كم توجهى_بيشفعالى، عدم وجود

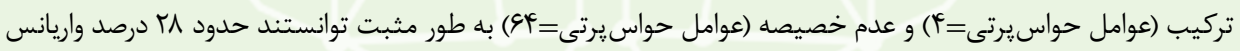
تخلفات راندگَى را پيشبينى كنند. نتيجه كيرى: با افزايش سن ميزان تخلفات كزارششده كاهش مىيابد. رابطه مثبت بين داشتن اختلال كم توجهىــ بيشفعالى با تعداد كل تصادفها و تخلفات خودكزارشى، نشاندهنده توانايى ناكافى در توجه و تمركز، كنترل كم به شرايط و رفتارهاى تكانشى است كه مىتواند منجر به اين رابطه شوند. همجنين با كاهش سن و قابليتهاى بالاى

$$
\text { جستجوى بينايى افراد ميزان تخلفات آنها افزايش مى يابد. }
$$

دريافت:

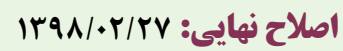

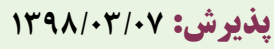

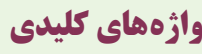
جستجوى بينايى اختلال بيشفعالى_كمتوجهى ينايى تخلفات رانندگى احتى نويسنله مسئول سيد حجت زمانى ثانى، استاديار تروه

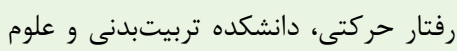

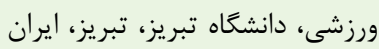

ايميل:Hojjatzamani8@gmail.com

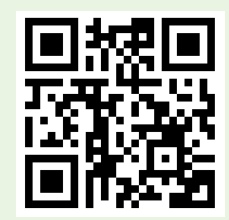

dol doi.org/10.30699/icss.22.1.1
را به هدر مىدهد ( (1). امروزه با توجه به كثرت وسايل نقليه و افزايش روزافزون توليد و فروش خودرو و همجنين افزايش سرعت در حمل و نقل و عدم رشد ايمنى با همان سرعت، تصادفات رانندگى حجم زيادى از
در كشورهاى در حال توسعه مانند ايران، تصادفات رانندگى يكى از عوامل مرك و مير و صدمات مالى و جانى مهلم به شمار مىرود. ضرر و زيان ناشى از تصادفات، سالانه // / درصد توليد ناخالص ملى كشورهاى در حال رشد 
درك خطر، افزايش توانايى در شناسايى و انتخاب محركهاى مورد نظر و همجنين كاهش زمان واكنش، كاهش مىيابد (1)). همجنين در مقايسه با موقعيتهاى خنتى، در شرايط عصبانيت، راندكَى سريعتر

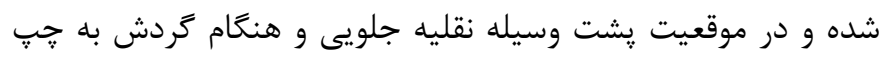

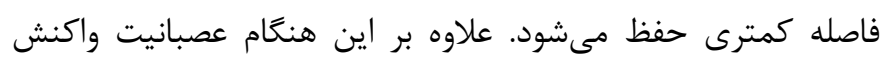

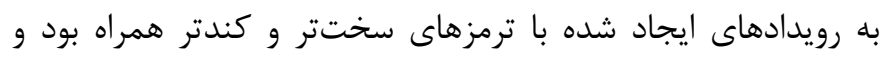
نشاندهنده شكست در ياسخ مناسب به تصادفهاى قريب الوقوع است كه در كنارههاى جاده ايجاد مىشود. نتايج حركات جشمى نيز نشان

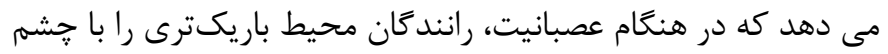
بررسى مىكنند و يك سبك يردازشى موشكافانهاى دارند كه هر دو منجر به افزايش احتمال خطاها در محيط اطراف مىشود. همجنين

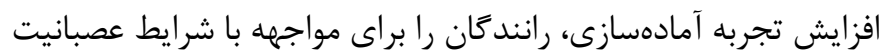

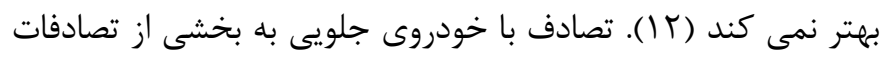

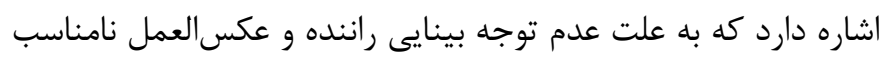

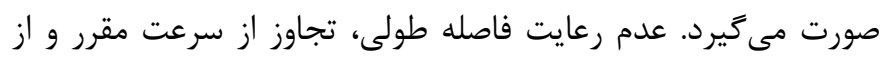

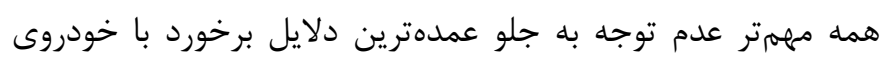
جلويى به شمار مىروند (1). بيشترين عامل در تصادفات كردش به به بهات جֶ) خطاهاى ناشى از عدم و يا كمبود توجه كزارش شدهاند كه اين عامل در راندكان مسنتر شش برابر بيشتر ززارش شده است (19). در زندگى روزمره، اغلب اوقات ما به جستجوى فعال محركهاى خاص رداص

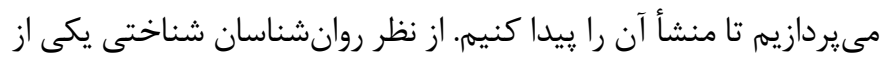

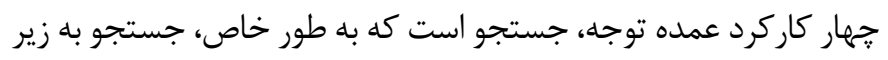

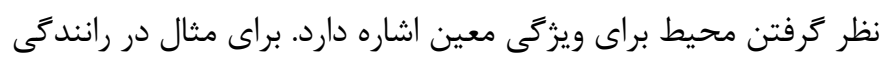

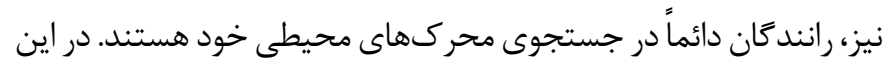

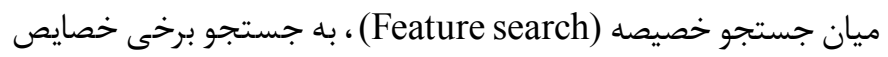

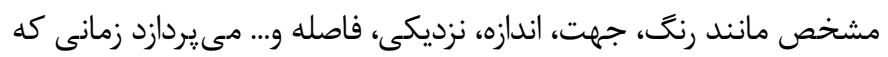
فقط محيط را براى آن خصوصيت يا خصايص مورد بررسى قرار دهيم. همجنين در جستجوى تركيبى (Conjunction search)، ما به دنبال تركيب خاص (به هم بِيوستكى) خصايص مانند تركيب فاصله و جهت هستيم. به عقيده Wolfe، يكى از نظريات مطح در حيطه جستجو،

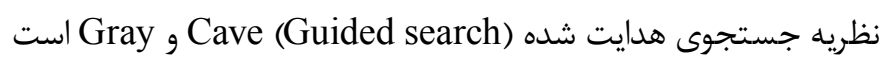

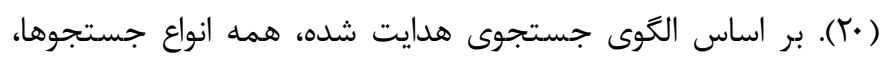
جه خصيصه و خه تركيبى، شامل دو مرحله بِيايى هستند. اول، مرحله

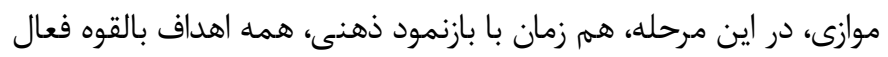

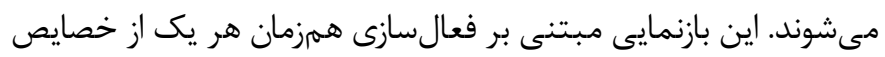
هدف است. در مرحله متوالى بعدى، فرد به صورت متوالى ميزان

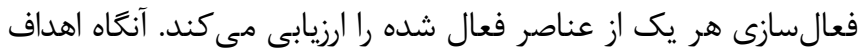

خسارات وارده به انسان را شامل مىشود. ميزان خسارتهاى ناشى از

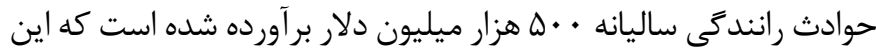
خسارتها شامل هزينههاى بيمارستانى، از كار افتادگى و خسارتهاى

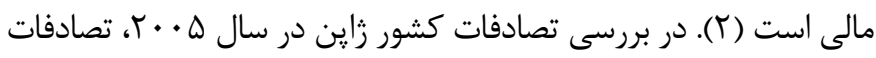

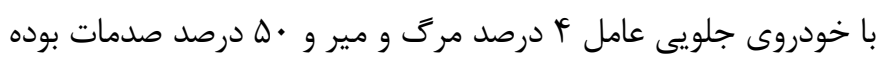

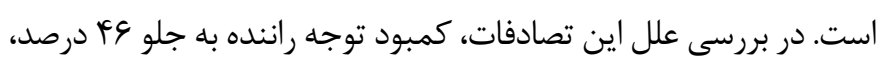

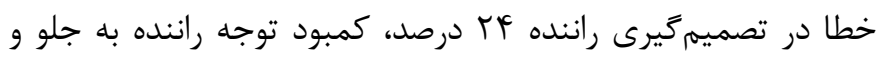

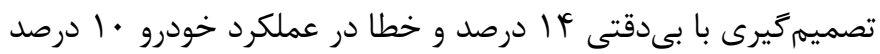
كزارش شده است (َّ). كمتوجهى و حواسيرتى رانند از علل بزرگ سوانح ترافيكى مطرح است. بخشى از توانايى توجه راعوامل

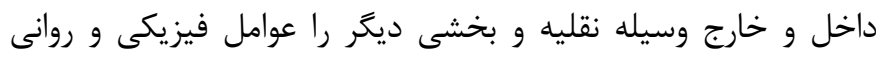

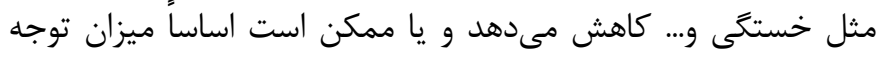

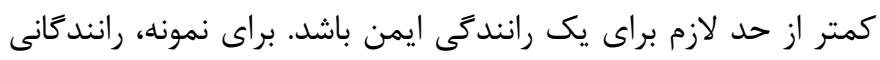

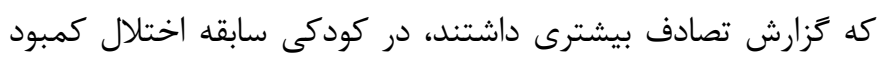

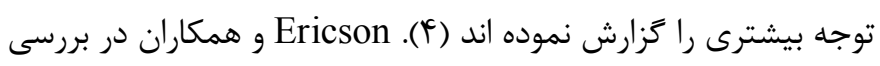

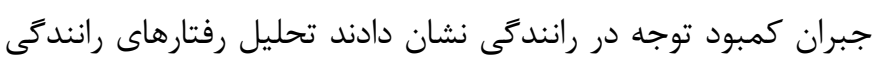

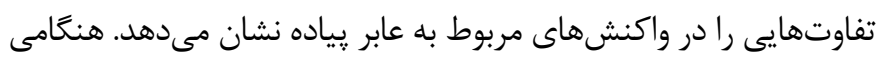
كه بار توجهى ميدان ديد كمتر باشد، رانندكان سرعت ترمز بيشتر و انحراف از فرمان ماشين كمترى نشان مى دهند. همجنين محيطهايى كه

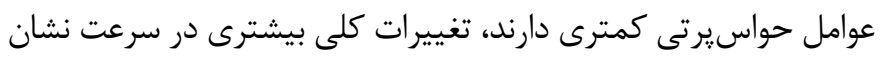
مى دهند (ه). رفتار شناختى ضعيف رانندگى، علت اصلى تصادفات است.

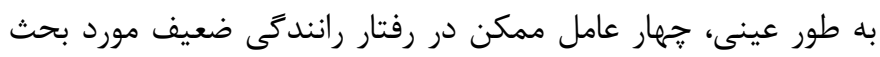

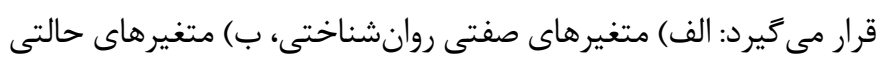

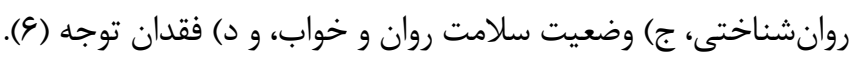

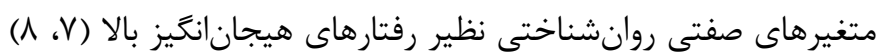

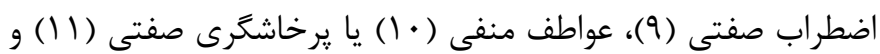
خشونت صفتى (T) با عملكرد ضعيف رانندكى همراه بودند. علاوه

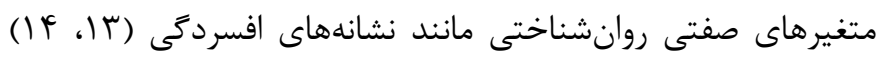

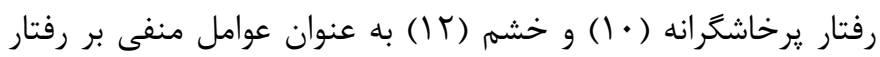

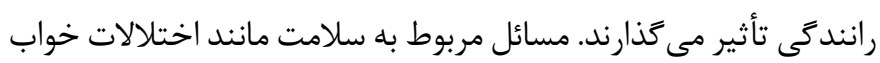

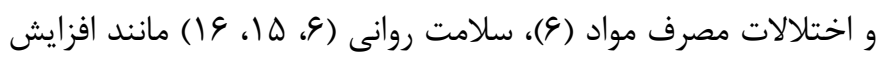

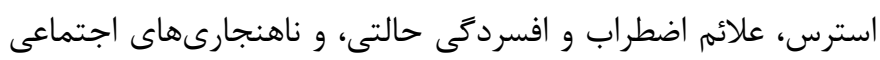

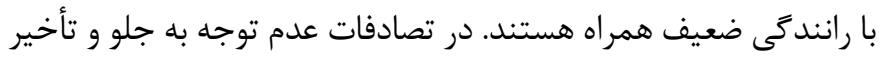
در واكنش مىتواند سبب تصادف و حادثه شود. بنابراين عدم توجه به

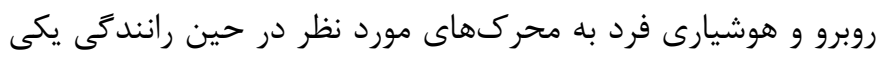

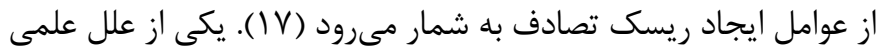

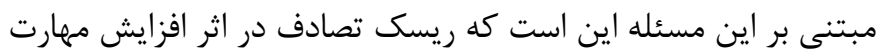


نقليه در طول سر گردانى ذهنى براى هر دو سطح بار ادراكى بالاو يايين

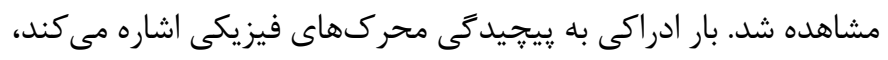

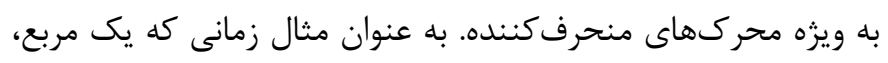
توسط دايرهها احاطه شده باشد، صحنه داراى بار ادراكى كمى است.

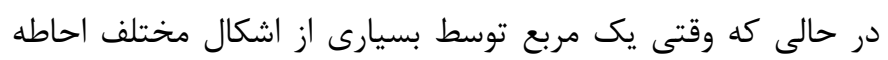

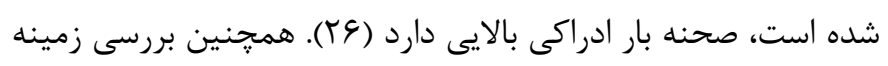

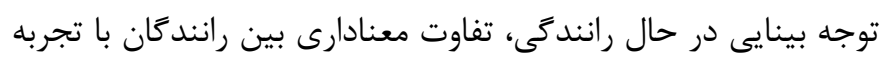

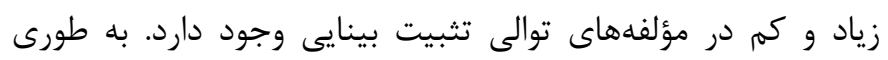

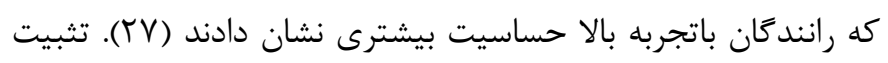

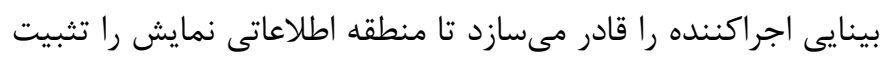

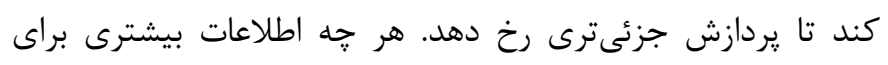

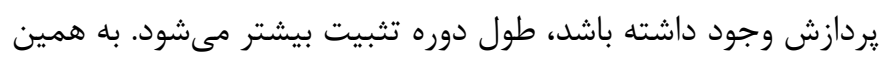

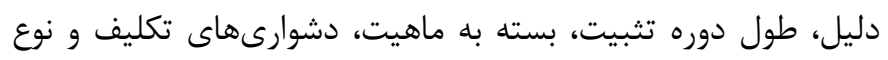

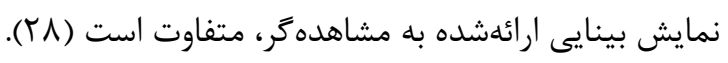

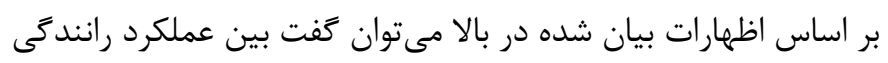

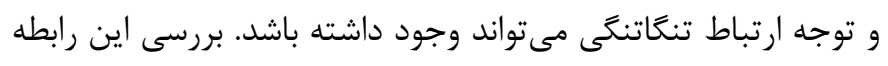

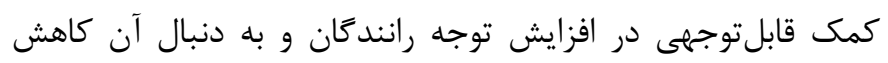

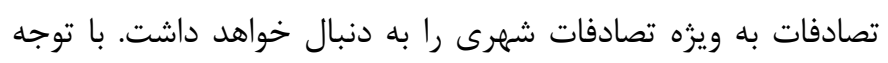
به مباحث مطرح شده هدف از انجام تحقيق حاضر، بررسى رابطه بين

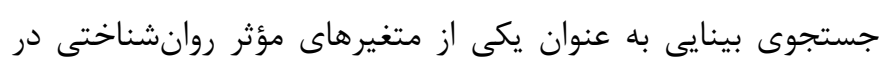

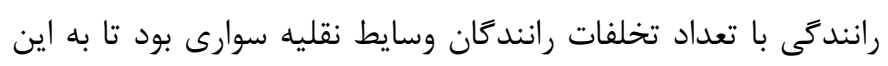

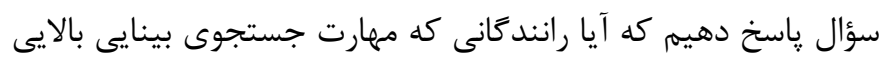

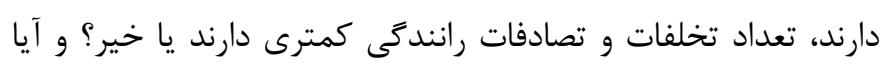

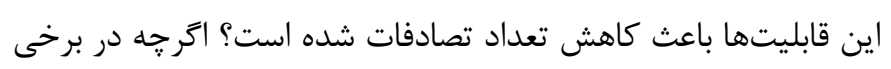

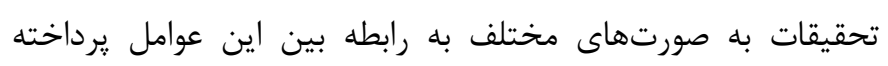
شده است، با اين حال بررسى رابطه بين جستجوى بينايى و ميزان

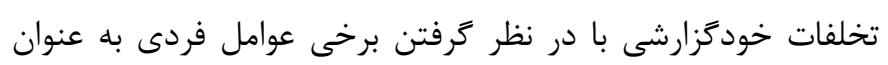

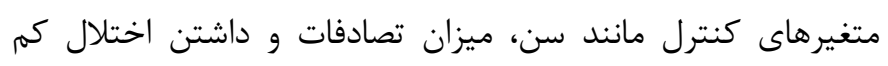

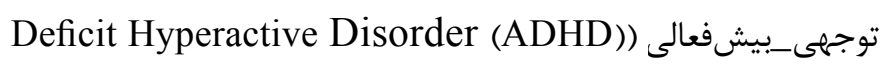
فرد مىتواند متغيرهاى مزاحم موجود در اين زمينه رال (Attention

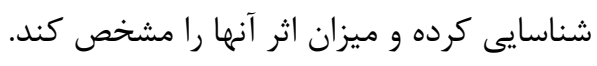

\section{روش كار}

مطالعه حاضر بر اساس هدف مطالعه كاربردى بود كه به روش همبستخى

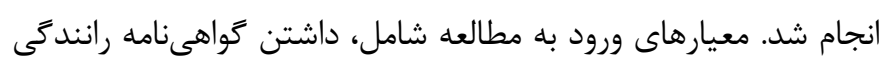

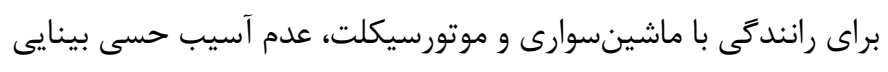
و شنوايى غيرقابل اصلاح، قابليت خواندن و نوشتن و عدم مشكلات ورئ روانى
واقعى را از بين عناصر فعال شده انتخاب مىنمايد. بر اساس اين الكو، فرآيند فعالسازى مرحله موازى اوليه به هدايت فرآيند ارزيابى و

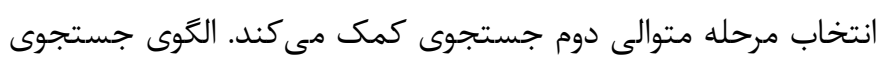
هدايتشده بِيشبينى مى كند كه برخى از جستجوهاى تركيبى آسانتر

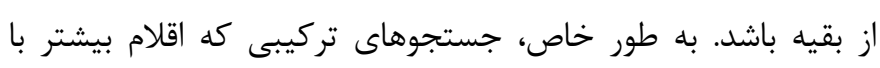

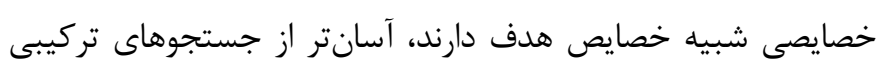

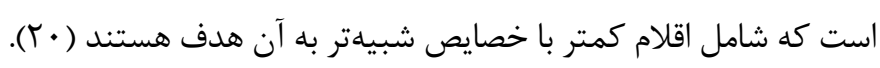

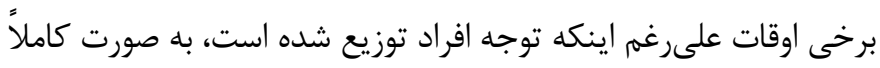

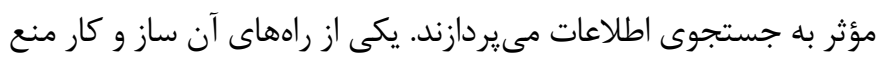

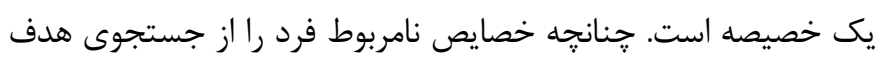

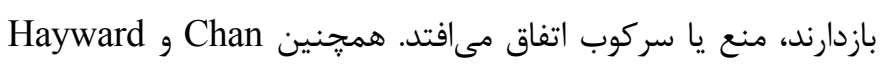

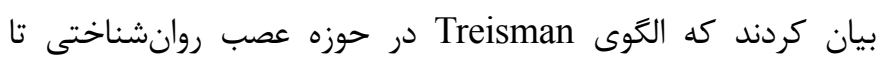
حدودى مورد حمايت قرار كرفته است. بر اساس نظريه تلفيق خصيصه خصائ (Feature-integration theory)

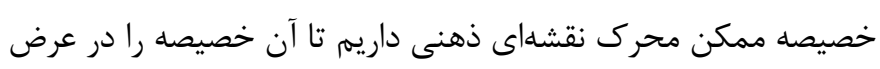

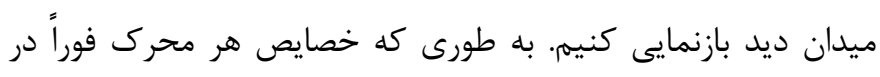

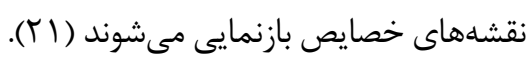

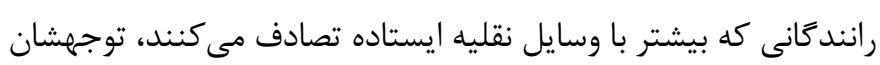

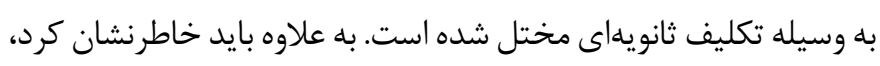
تكاليف توجه انتخابى در آزمايشًاه (Tr) و تكاليف تغيير توجه (T) براى بيشبينى تصادفات ترافيك مورد استفاده قرار كرفتهاند و نتايج

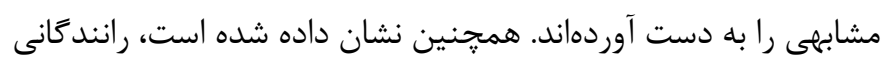
كه توسعه راهبردهاى توجه دارند و مىتوانند روى مناطق خطر آند آفرين

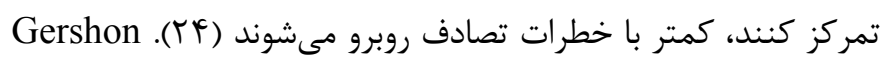
و همكاران در بررسى وضوح جستجو و توجه به موتورسيكلت سوارها

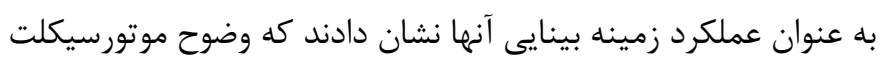

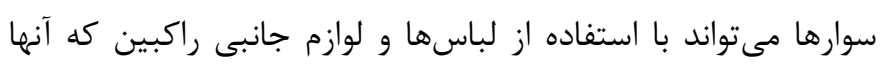

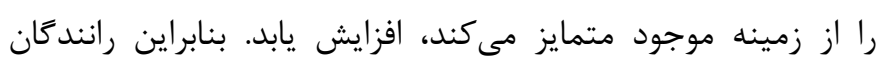

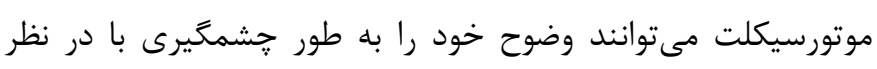

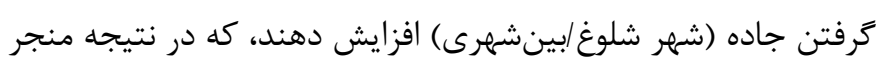

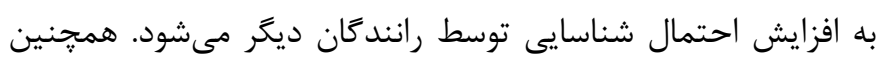

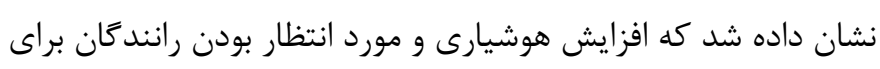

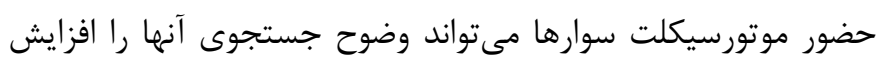

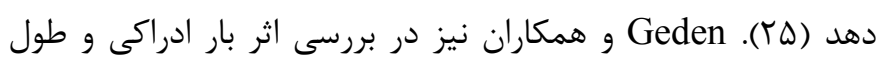
مدت راندگ

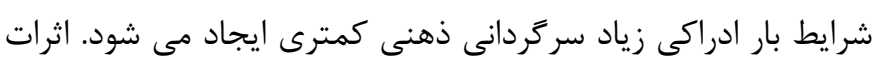
غيرخطى معنادارى براى طول مدت رانندگى در زمينه كنترل وسيله 
رانندگى يليس نيروى انتظامى جمهورى اسلامى ايران استخراج شد. اين تخلفات به صورت سؤال و در يك مقياس ليكرت ثأ گزينهاى مورد بررسى قرار كرفت. از آنجايى كه اطلاعات موجود در يليس فقط تخلفات

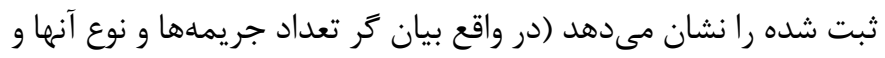
نه همه تخلفات انجام شده) لذا در اين تحقيق تخلفات انجام شده توسط

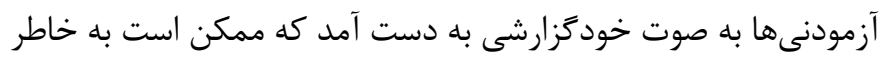

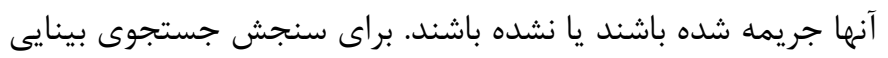

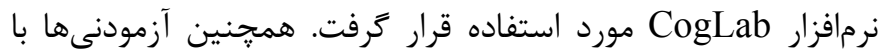
استفاده از يرسشنامه اختلال كم توجهى_بيشفعالى بزركسالان مورد بر برسى قرار كرفتند. نرمافزار CogLab: شامل جندين آزمون روانشناسى شناختى است. اين نرمافزار به كونهاى طراحى شده است كه در هر كوشش يك نقطه

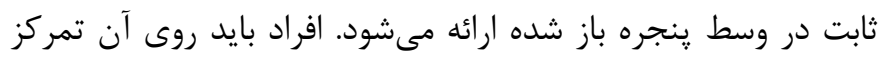

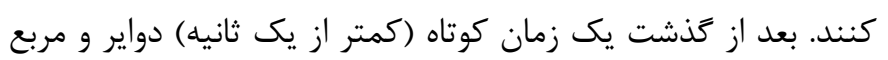

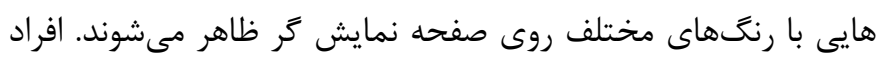

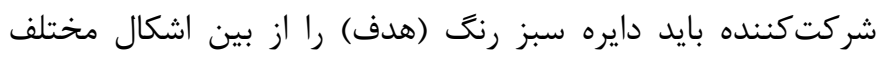
تشخيص دهند. وقتى آنها دايره سبز رنگ را تشخيص دادند، كليد مورد نظر را فشار مىدهند. در برخى كوششها دايره سبز رنخ وجود نخواهد داشت كه در اين صورت كليد ديگرى را بايد افراد فشار دهند. ابزار مورد نياز براى سنجش متغيرهاى جستجوى بينايى يك دستكاه لِ تاب

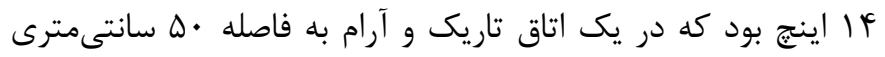

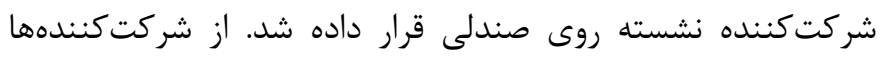

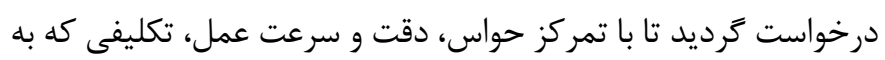

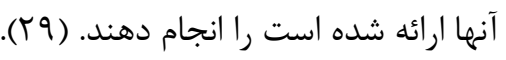

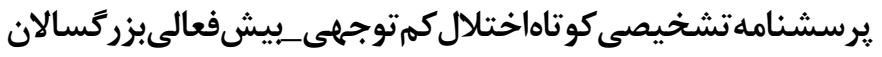
(Adult ADHD Self-Report Scale-V1.1 (ASRS-v1.1)) 11 معيار تشخيصى DSM-IV-TR را شامل مىشود. شواهد نشان

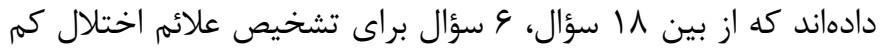
توجهى_بيشفعالى از توان بيشترى برخوردار هستند. اين 9 سؤال شالوده

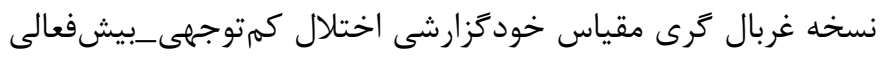

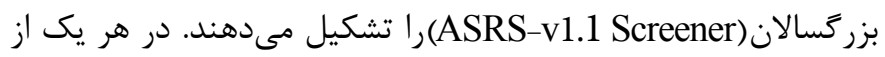

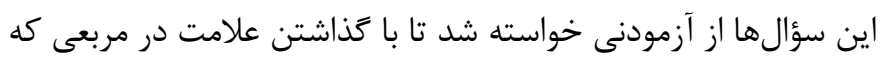

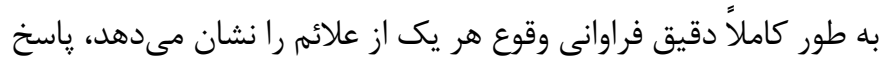

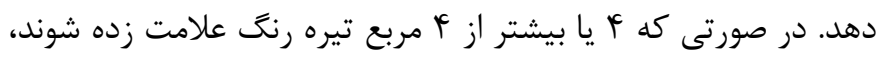

بيمار از علائم اختلال كمتوجهى_بيشفعالى رنج مىبرد (• آ، آس). براى تجزيه و تحليل دادهها از ميانگين، انحراف استاندارد و درصدهابراى آمار توصيفى استفاده شد. به منظور بررسى آمار استنباطى از همبستخى دجى دانى
مزمن بود كه از طريق خودگزارشى به دست آمد. همجنين معيارهاى

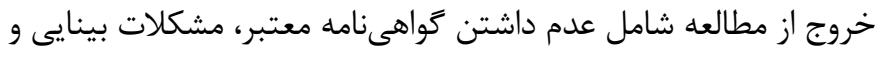
شنوايى مزمن غيرقابل اصلاح، عدم سواد كافى براى خواندن و نوشتن،

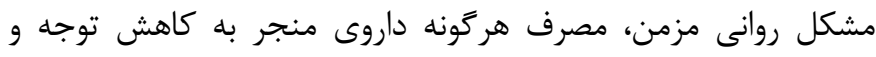

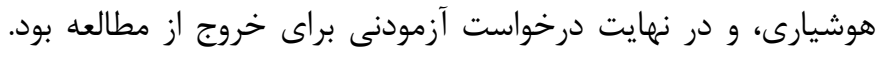

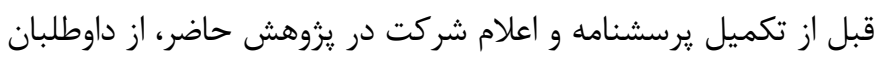

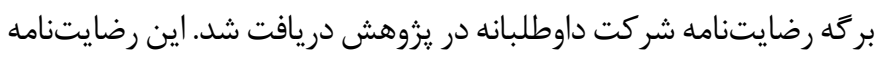
آكاهانه بر اساس استانداردهاى جهانى شامل هدف يزوهش، اطمينان از محرمانه بودن اطلاعات، عدم استفادههاى تجارى و غيرعلمى از اطلاعات آنها، حفظ حريم خصوصى افراد، آزاد بودن براى شركت و يا عدم شركت در تحقيق بود. اين رضايتنامه به صورت كتبى توسط همكاران طرح

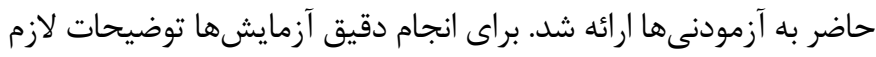

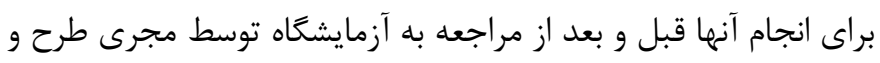

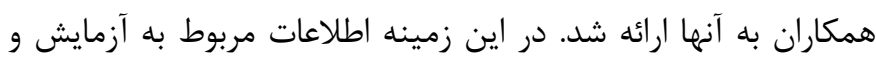

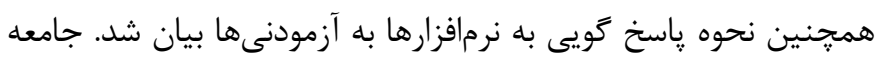

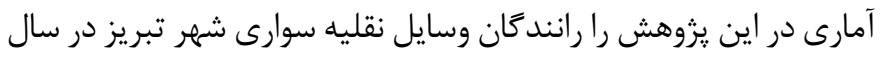

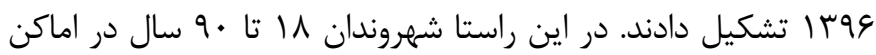
مختلف شهر تبريز مورد سؤال قرار گرفتند. براى انتخاب نمونهها از روش

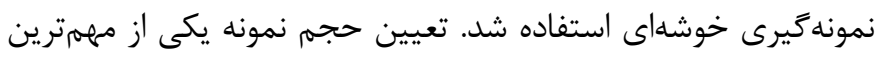

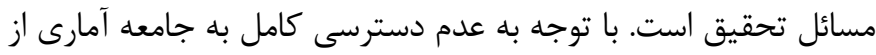
روش تعيين نمونه كوكران استفاده شد به طورى كه افراد مسبب سانحه

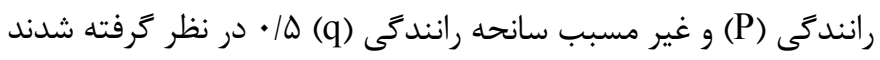

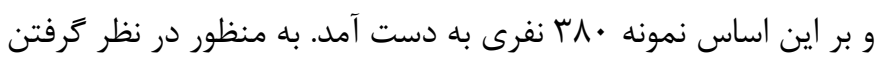

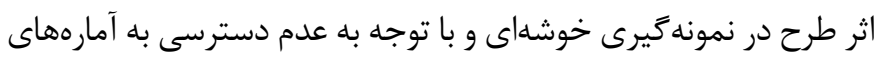

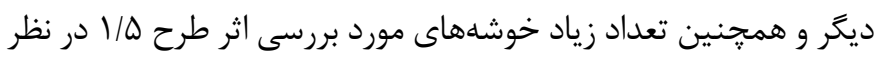

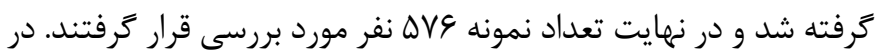

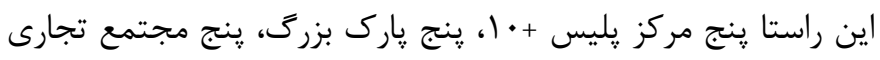
و فروشگاه زنجيرهاى، ينج مركز آموزشى و دانشآهى، سينماها و مراكز

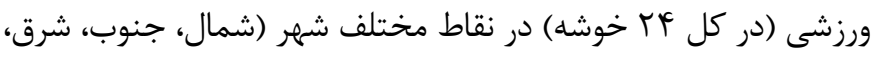

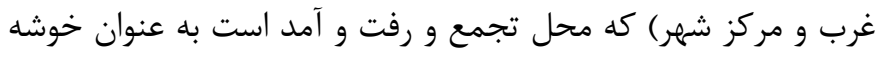

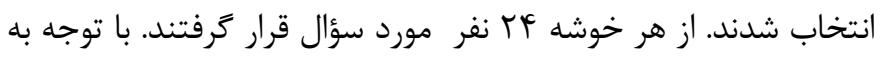

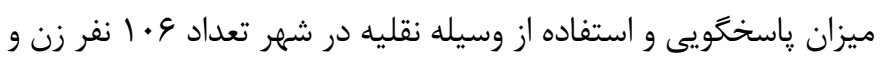

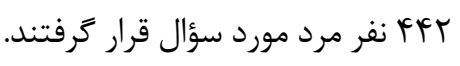
براى سنجش اطلاعات فردى از قبيل سن، جنسيت، تعداد تصادفات،

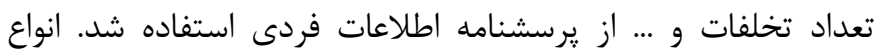
تخلفات احتمالى مربوط به بينايى با توجه به نظر متخصصين بركرفته

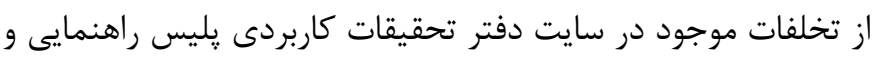


شدت افزايش يافت و همجنين زمان واكنش در صورت عدم وجود تركيب به ميزان بيشترى نسبت به وجود تركيب در تأثير تعداد عوامل حواسيرتى افزايش يافت (عدم وجود تركيب از أF/MF r r/A در كل با توجه به محدوديتهاى موجود در تعداد زنان و مردانى كه از وسيله نقليه شخصى استفاده مى كنند، צ. انفر زن (ז/9 ا درصد) در كل نمونه مورد بررسى قرار زرفت. از اين

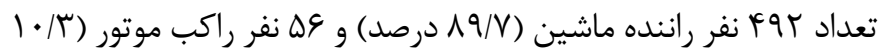
درصد) بودند. در بين اين افراد اqس نفر به طور روزانه (Y//

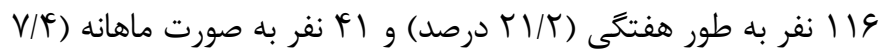
درصد) از وسيله نقليه استفاده مى كردند. در جدول r به بررسى روابط بين متغيرهاى فردى و ميزان تخلفات خود گزارشى اشارهشده است. بدين منظور از ضريب همبستخى پيرسون و اسييرمن استفاده شد (جدول ؟).
ييرسون و همبستخى جزئى و رگرسيون جند متغيره به روش اينتر در سطح معنادارى ه • • • با استفاده از نرمافزار

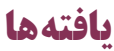

آمارههاى توصيفى يزوهش حاضر در جدول ا نشان داده شد. با توجه به افت آزمودنىها در تحليل دادهها تعداد هFA نفر مورد تحليل قرار كرفتند.

همان طور كه انتظار مىرفت و بر اساس نظريههاى مربوط به جستجوى بينايى، در مورد وجود و عدم وجود خصيصه با افزايش تعداد عوامل حواسيرتى (از F تا FF) زمان واكنش تغيير اندكى مى كند (به ترتيب

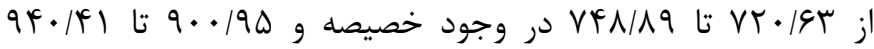
در عدم وجود خصيصه). با اين حال در جستجوى وجود يا عدم وجود تركيب با افزايش تعداد عوامل حواسيرتى، زمان واكنش به

جدول ا. شاخصهاى آمار توصيفى براى متغيرهاى يزوهش

\begin{tabular}{|c|c|c|c|c|c|c|c|c|}
\hline خطاى استاندارد & آماره & خطاى استاندارد & آماره & معيار & ميانَين & حداكثر & حداقل & جستجوى بينايى \\
\hline$\cdot / r \cdot \Lambda$ & $1 / 99$ & $\cdot 11 \cdot r$ & I/VTr & TTV/T. & $1111 / \mathrm{kF}$ & $r \cdot \mid f / g r$ & $\varepsilon \Delta \Gamma / \Delta$. & عدم وجود تركيب \\
\hline$\cdot / r \cdot \Lambda$ & $1 / \pi \Delta$ & $\cdot 11 \cdot 4$ & $1 / \Lambda \Delta$ & $r I I / \Delta$. & $\Lambda \& M / A F$ & $T \cdot N N / I T$ & $\Delta \Delta T / I T$ & وجود تر كيب \\
\hline$\cdot / r \cdot \Lambda$ & $1 / 19$ & $\cdot 11 \cdot 4$ & $1 / 4$. & re./Et & $9 \cdots / 90$ & тrтq/.. & FVV/TD & عدم وجود خصيصه \\
\hline$\cdot / r \cdot \Lambda$ & $1 / r V$ & $\cdot 11 \cdot 4$ & $1 / \Lambda$ & rra/v. & $V T \cdot \mid \& T$ & $r \cdot \mid \Lambda / T V$ & FIV/VD & وجود خصيصه \\
\hline$\cdot / r \cdot \Lambda$ & .109 & $\cdot / 1 \cdot 4$ & $\cdot / V \Delta$ & $F \cdot N / \Delta r$ & IQVQ/AT & TAMT/.. & $V T I / \Delta$. & عدم وجود تركيب \\
\hline$\cdot / r \cdot \Lambda$ & $1 / r \wedge$ & $\cdot 11 \cdot 4$ & $1 / 49$ & $r \Lambda \Delta / F \Lambda$ & 11.9194 & TVDD/GT & $\Delta q Y / I T$ & وجود تركيب \\
\hline$\cdot / r \cdot \Lambda$ & $\Delta / V F$ & $\cdot 11 \cdot f$ & $1 / \Lambda \Delta$ & rIT/VV & $\Lambda V F / \Delta$. & $r \wedge 1 \cdot \%$ & FFeIIT & عدم وجود خصيصه \\
\hline$\cdot / r \cdot \Lambda$ & $1 / \mu F$ & $\cdot 11 \cdot 4$ & $1 / V r$ & TFT/YG & VTE/TF & rIS9/Tr & $f \mid \Delta / \Delta$. & وجود خصيصه \\
\hline$\cdot / r \cdot \Lambda$ & $1 / T V$ & $\cdot 11 \cdot 4$ & $\cdot \mid \Lambda \Lambda$ & VEY/qI & 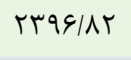 & $\Delta F q \Lambda / V \Delta$ & $\Lambda \Lambda F / T \Delta$ & عدم وجود تركيب \\
\hline$\cdot / r \cdot \Lambda$ & $1 / \mu$. & $\cdot 11 \cdot 4$ & $\cdot \mid \Lambda \Lambda$ & FTERE & $\mid \Delta \& T / \Delta \cdot$ & TrQN/D. & $V \Delta \cdot / \pi V$ & وجود تركيب \\
\hline$\cdot / r \cdot \Lambda$ & I/VF & $\cdot 11 \cdot 4$ & $1 / 49$ & 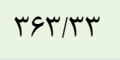 & $q 4 \cdot|4|$ & $r V \cdot F / A V$ & FFVIIT & عدم وجود خصيصه \\
\hline$\cdot / r \cdot \Lambda$ & $1 / 11$ & $\cdot 11 \cdot r$ & $1 / 4 V$ & THN/DQ & $V F N / \Lambda 9$ & $T \cdot I T / \Delta$. & $F \Delta T / Q$. & وجود خصيصه \\
\hline$\cdot / r \cdot \Lambda$ & .109 & $\cdot / 1 \cdot 4$ & • & $9 / \cdot 1$ & $r \Delta / r \Lambda$ & 99 & TI & ميزان تخلفات (خودكزارشى) \\
\hline$\cdot / r \cdot \Lambda$ & $-\cdot / \Delta r$ & $\cdot 11 \cdot 4$ & $\cdot / 4 q$ & $1 / 4 q$ & $1 / \wedge \Delta$ & 4 & . & ADHD \\
\hline$\cdot / 4 \cdot \Lambda$ & ( & $\cdot 11 \cdot r$ & $1 / \cdot F$ & $q / \vee \Delta$ & $r / / r V$ & 90 & 19 & سن (سال) \\
\hline (TIK & $1 / 94$ & $.11 \cdot 9$ & $T / T G$ & $1 / 9 V$ & $1 / r$. & 1. & - & تعداد تصادفات \\
\hline
\end{tabular}


به رانندگى با تخلفات رانندكان وسايط نقليه سوارى شهر تبريز از ضريب ركرسيون استفاده شد، به طورى كه ميزان تخلفات رانندكان به عنوان متغير ملاك و جستجوى بينايى و متغيرهاى ديخر به عنوان متغير يیشبين وارد مدل شدند. يِشفرضهاى اصلى رگرسيون خطى شامل: نرمال بودن توزيع متغير

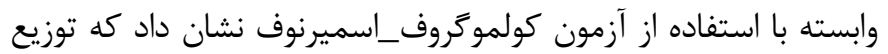

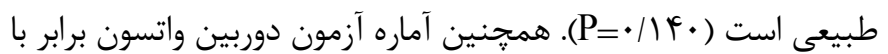
1 • • ب نشاندهنده استقلال مقادير باقىمانده يا خطاها بود. علاوه براين همبستخى خطى بين متغيرها در جداول r و ب بيان شده است. همجنين متغيرهاى ييشبين و ملاك در مقياس ييوسته اندازهگيرى شده بودند. نتايج نشان داد كه مدل قابليت يُيشينى متغير ملاك را از روى متغيرهاى
در ادامه به بررسى روابط بين جستجوى بينايى با ميزان تخلفات راندكى غرداخته شد (جدول ؟). به منظور تعديل شرايط احتمال تصادف، تعداد تصادفات انجام شده، سن

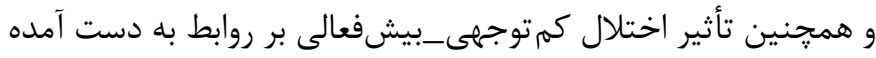

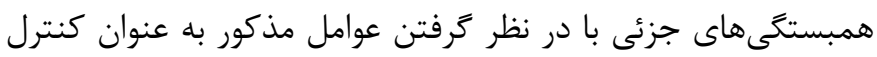
مورد بررسى قرار كرفت (جدول f). همانطور كه مشاهده مى

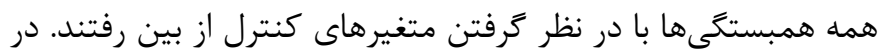
واقع نشان داده شد كه عوامل ديخرى غير از عوامل جستجوى بينايى مىتواند در ميزان تخلفات رانندگى تأثير كذار باشد كه روى رابطه بين جستجوى بينايى و تخلفات رانندگى تأثير خواهند داشت. به منظور بررسى رابطه بين جستجوى بينايى متغيرهاى ديگر مربوط

جدول r. همبستخى (پيرسون و اسيّرمن) بين متغيرهاى فردى يزوهش

\begin{tabular}{|c|c|c|c|c|}
\hline ADHD & تعداد تصادف & سن (سال) & & \\
\hline & & $\cdot / \cdot \Delta V$ & ضريب همبستكى & \multirow[b]{3}{*}{ 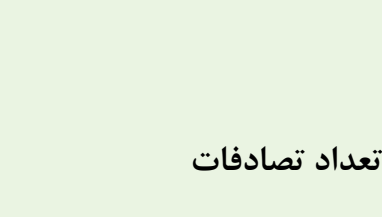 } \\
\hline & & .1190 & $\mathbf{P}$ & \\
\hline & & DTS & تعداد & \\
\hline & 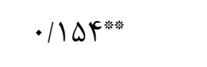 & $-\cdot / \cdot \Delta \Delta$ & ضريب همبستكى & \multirow{3}{*}{ ADHD } \\
\hline & $\cdot \mid \cdots \cdot$ &.$/ 197$ & $\mathbf{P}$ & \\
\hline & DTS & $\Delta F \lambda$ & تعداد & \\
\hline . & $\cdot / r \cdot q^{\circ * 0}$ &.$- / \Gamma 19 \circ$ & ضريب همبستكى & \multirow{3}{*}{ ميزان تخلفات (خودكزارشى) } \\
\hline$\cdot|\cdots|$ & $\cdot|\cdots|$ &.$|\cdots|$ & $\mathbf{P}$ & \\
\hline$\Delta F \Lambda$ & $\Delta T \varphi$ & $\Delta F \Lambda$ & تعداد & \\
\hline
\end{tabular}

جدول r. رابطه بين جستجوى بينايى با تخلفات رانندًان

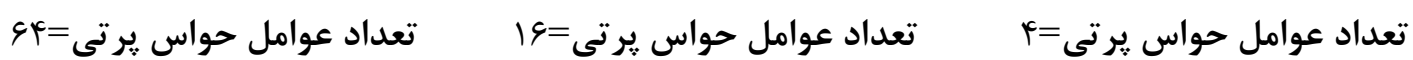

\begin{tabular}{|c|c|c|c|c|c|c|c|c|c|c|c|c|c|}
\hline خصيصه & خصيصه & تركيب & تركيب & خصيصه & خصيصه & تركيب & تركيب & خصيصه وجود & خصيصه & تركيب & تركيب & & \\
\hline$-\cdot / r \mid r^{* * *}$ & r & $-.1 .9 r^{*}$ &.$- / . p q$ & $-\cdot / \Gamma \ldots$ & $-\cdot / 1 r \xi^{* *}$ & $-\cdot / l \uparrow \cdot *$ & $-\cdot / 1 \cdot V=$ & $-\cdot / / \Lambda^{* * * *}$ & $-\cdot / 14 \cdot *$ & $-\cdot / r \cdot r^{*}$ & $-\cdot / 11 \mathrm{~V}^{\text {* }}$ & همبستخغى & \\
\hline$\cdot \mid \cdots 1$ & - /lFF & . & $\cdot \pi \cdot \Delta$ & $\cdot 1 . .1$ & $.1 . .1$ & $.1 . .1$ &.$/ .14$ & $\cdot|\cdots|$ & $.1 . .1$ & $\cdot 1 \cdot \cdots 1$ & .1 .94 & $\mathbf{P}$ & تخلفات \\
\hline$\Delta F \Lambda$ & $\Delta F \Lambda$ & $\Delta F \Lambda$ & $\Delta F \lambda$ & $\Delta F \Lambda$ & $\Delta F \Lambda$ & $\Delta F \Lambda$ & $\Delta F \Lambda$ & $\Delta F \Lambda$ & $\Delta F \Lambda$ & $\Delta F \Lambda$ & $\Delta F A$ & آزادى درجه & \\
\hline
\end{tabular}




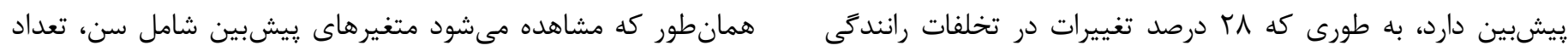

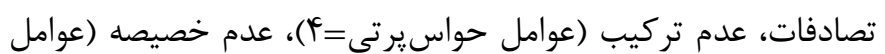
تحت تأثير متغيرهاى بيشبين به دست آمد كه اين تغيير يذيرى با مقدار

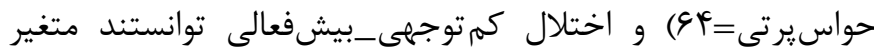
ملاك ميزان تخلفات راندگى را پيشيشى كنيند.

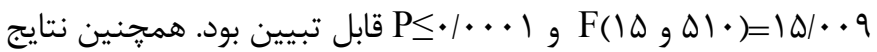
ضرايب تأثير متغيرها در جدول ه بر اساس اين مدل آورده شده است.

جدول أ. رابطه بين جستجوى بينايى با تخلفات راندكان با در نظر كرفتن متغيرهاى كنترل

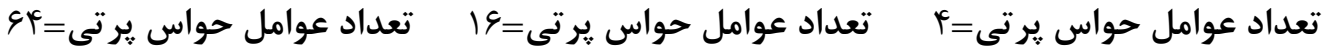

\begin{tabular}{|c|c|c|c|c|c|c|c|c|c|c|c|c|c|c|}
\hline خصيصه وجود & خصيصه & تركيب & تركيب & خصيصه وجود & خصيصه عدم & تركيب & تركيب & خصيصه وجود & خصيصه & تركيب & تركيب & \multicolumn{3}{|c|}{ متغير هاى كنترل } \\
\hline$-.1 .4 v$ & $\cdot / \cdot \Delta V$ &.$/ .1 \pi$ & 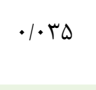 & $-\cdot / \cdot r \Lambda$ & $-\cdot / . \top \Lambda$ &.$- / . \cdot r$ & .1 .11 & -.1 .95 &.$- / . T V$ & $-\cdot|\cdot| \psi \mid$ & $\cdot 1 \cdot v 1$ & ضمبستخى & & \\
\hline - / rVq &.$/ 195$ & •/VA1 & . ATq & $\cdot / r \Lambda A$ & - /DTA & $\cdot / 981$ & $\cdot \mid \lambda \cdot F$ & $\cdot / 1 \Delta \Lambda$ & . & $\cdot / r \Delta \cdot$ & $\cdot 11 \cdot r$ & $\mathbf{P}$ & 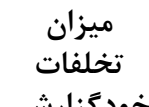 & تصادف ها، \\
\hline$\Delta T_{1}$ & $\Delta T^{\prime}$ & $\Delta T_{1}$ & $\Delta T_{1}$ & $\Delta T_{1}$ & $\Delta T_{1}$ & QTI & $\Delta T_{1}$ & $\Delta T_{1}$ & $\Delta T_{1}$ & $\Delta T_{1}$ & $\Delta T_{1}$ & آزادى درجه & & \\
\hline
\end{tabular}

جدول ه. نتايج ضرايب تأثير متغيرها در مدل

\begin{tabular}{|c|c|c|c|c|c|}
\hline \multirow{2}{*}{$\mathbf{P}$} & \multirow{2}{*}{$\mathbf{t}$} & \multirow{2}{*}{ ضرايب استاندارد نشده } & \multicolumn{2}{|c|}{ ضرايب استاندارد نشده } & \multirow{2}{*}{ 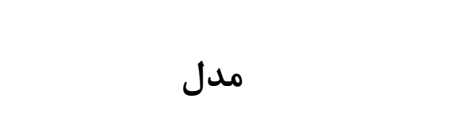 } \\
\hline & & & انحر اف معيار & $\mathbf{B}$ & \\
\hline$\cdot 1 \cdot \cdot 1$ & $r I / r V$ & & l/Ar & rq/lr & ثابت \\
\hline$\cdot 1 \cdot \cdots 1$ & -G/DTK & $-\cdot / r \Lambda \Lambda$ &.$/ \cdot$ tr & $-\cdot / 4 V I$ & سن \\
\hline $.1 \cdots 1$ & $V / V I$ & $\cdot / r q 4$ & . ITFV & $1 / 9 \cdot r$ & ADHD \\
\hline$\cdot 1 \cdot \cdots 1$ & $V / \pi q$ & . TAN & $\cdot / r \cdot V$ & $1 / \Delta T$ & تعداد تصادفات \\
\hline$\cdot / \cdot r$ & 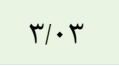 & .119 & $\cdot 1 \cdot r$ & $\cdot 1 \cdot \cdot \Delta$ & عدم تركيب (عوامل حواسيرتى =F) \\
\hline$\cdot / T F V$ & $-1 / 1 \Delta \Lambda$ & $-.1 \cdot 94$ & $\cdot / \cdot r$ & $-\cdot \cdot \cdot \cdot r$ & وجود تركيب (عوامل حواسير تى =F) \\
\hline $.1 \cdot 9$ & $-1 / V \cdot 1$ & $-\cdot 11 \cdot 9$ &.$/ \cdot r$ & $-\cdot / \cdot \cdot r$ & عدم خصيصه (عوامل حواسيرتى=ff) \\
\hline .1199 & $-1 / T \wedge \Delta$ & $-\cdot / \cdot \wedge$ &.$/ \cdot r$ & $-\cdot / \cdot \cdot r$ & وجود خصيصه (عوامل حواسيرتى =f) \\
\hline$\cdot 1199$ & $-1 / T \wedge \Delta$ & $-\cdot 1 \cdot 91$ &.$/ \cdot r$ & $-\cdot / \cdot r$ & عدم تركيب (عوامل حواسيرتى==1) \\
\hline.$/ 4 \pi$ & $\cdot|\lambda r|$ & $\cdot 1 \cdot 4 \Delta$ &.$/ \cdot r$ & $-\cdot \cdot \cdot \cdot 1$ & وجود تركيب (عوامل حواسيرتى=|\&) \\
\hline$\cdot / r \Delta F$ & $-1 / 1 / 4$ & $-\cdot 1 \cdot \vee 9$ & $\cdot / \cdot r$ & $-\cdot / \cdot \cdot r$ & عدم خصيصه (عوامل حواس يرتى=19) \\
\hline .1994 & $-\cdot / 49 \vee$ & $-\cdot / \cdot r V$ & $\cdot / \cdot r$ & $-\cdot 1 \cdot \cdot 1$ & وجود خصيصه (عوامل حواسيرتى=19) \\
\hline$\cdot|V T|$ & $\cdot r \Delta \Delta$ &.$/ \cdot r t$ & $\cdot 1 \cdot \cdot 1$ & $-\cdot \mid \cdot \cdot 1$ & عدم تركيب (عوامل حواسيرتى = عP) \\
\hline.$/ 914$ & $\cdot 11 \cdot 9$ & $.1 \cdot 9$ & $\cdot 1 \cdot \cdot 1$ & $-\cdot 1 \cdot \cdots 1$ & وجود تركيب (عوامل حواسيرتى = \\
\hline$\cdot / \cdot 1$ & D/rma & $\cdot|r|$ & $\cdot 1 \cdot r$ & $\cdot / \cdot \Delta$ & عدم خصيصه (عوامل حواسيرتى = \&F) \\
\hline .1949 & $-\cdot / \& \wedge \Lambda$ & 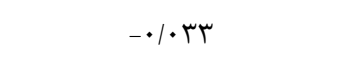 & $\cdot / \cdot r$ & $-\cdot 1 \cdot \cdot 1$ & وجود خصيصه (عوامل حواس يرتى =FF) \\
\hline
\end{tabular}


است. در همين راستا خطريذيرى به عنوان بيشبينى كننده آسيبهاى ترافيكى مطرح مىشود. اين يافتهها با نتايج Jerome و همكاران، همخوانى داشت. آنها در فراتحليل انجام شده، نشان دادند كه بين اختلال كمتوجهى_بيشفعالى و ميزان بالاى تصادفها و تخلفات، رابطه

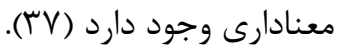
نتايج همبستخىها نشان داد كه رابطه منفى و معنادارى بين ميزان تخلفات رانندگى و جستجوى بينايى وجود دارد. در واقع نشان داده شد كه با افزايش ميزان تخلفات رانندگى قابليت افراد در زمان واكنش بهبود مىيابد. به نظر مىرسد افراد داراى زمان واكنش كمتر احتمال زيادترى دارد كه تخلفات رانندگى بيشترى انجام دهند. بدين صورت مىتوان نتيجه زمان واكنش خود دارد، دست به تخلف و قانونشكنى مىزنند. البته در نتيجه گيرى اين موضوع بايد كمى جانب احتياط را رعايت كرد. يزوهش حاضر از نوع همبستخى انجام شد و لزوماً نمى تواند روابط على و معلولى ليى براى متغيرهاى يزوهش باشد.

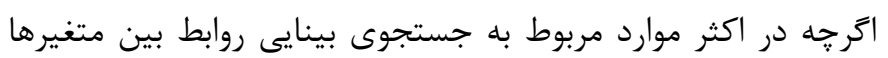
و ميزان تخلفات مشاهده شد، با اين حال همه روابط مشاهده شده در بررسى متغيرهاى كنترل از بين رفت كه مىتواند بيان گر اهميت موضوع سن، شاخص بالاى اختلال كمتوجهى_بيشفعالى و ميزان تصادفات در افراد باشد. به نظر مىرسد متغيرهاى فردى ذكر شده اهميت بيشترى نسبت به قابليت جستجوى بينايى افراد در ارتباط با ميزان تخلفات خود گزارشى داشته باشند. در همين ارتباط بررسى عوامل ييشبينى كننده ميزان تخلفات رانندگى از روى ويزگى هاى فردى و جستجوى بينايى نشان داده شد كه از بين متغيرهاى وارد شده در مدل سن، تعداد تصادفها، اختلال كمتوجهى_بيشفعالى، جستجوى عدم تركيب (عوامل حواسيرتى=|())، جستجوى عدم خصيصه (عوامل

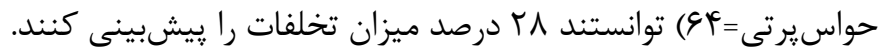
در واقع نشان داده شد كه با كاهش سن و افزايش ميزان تصادفات و نمره اختلال كمتوجهى_بيشفعالى ميزان تخلفات افزايش ييدا مى كند. همجنين در زمينه جستجوى بينايى در تحقيق حاضر هم از خصيصه و هم از تركيب براى بررسى ويزگى بينايى استفاده شد. همانطور كه در تحقيقات بيان شده است تركيب نسبت به خصيصه، تكليف دشوارترى براى جستجوى بينايى ايجاد مى كند. از طرف ديخر تعداد عوامل زياد

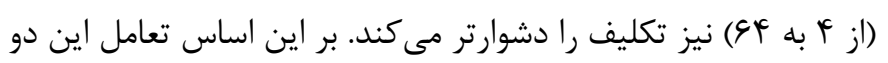
ويزگى تنها در عدم حضور هدف در تركيب با عوامل حواسيرتى يايين (f) و همجنين عدم حضور هدف در خصيصه با عوامل حواسيرتى زياد (F) توانستند به طور مثبت ميزان تخلفات رانندگى را ييشبينى
نتايج مطالعه نشان داد كه هرجه قدر افراد ميزان بالايى از جستجوى بينايى را دارا باشند، تخلفات بيشترى انجام مىدهند. همانطور كه انتظار مىرفت و بر اساس نظريههاى مربوط به جستجوى بينايى در نرمافزار مورد استفاده، در مورد وجود و عدم وجود خصيصه با افزايش

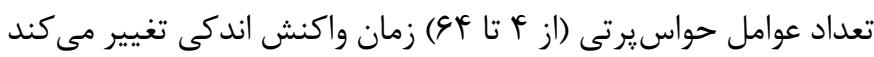
(به ترتيب از سع/•VT تا VYN/A

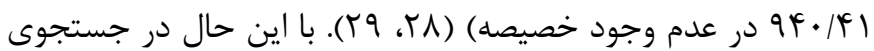
وجود يا عدم وجود تركيب با افزايش تعداد عوامل حواسيرتى، زمان واكنش به شدت افزايش يافت. همجنين زمان واكنش در صورت عدم وجود تركيب به ميزان بيشترى نسبت به وجود ارتباط در تأثير تعداد

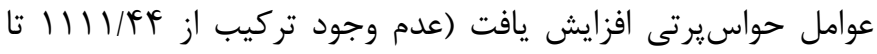

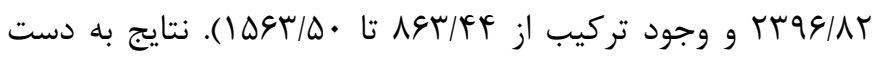
آمده با نظريههاى جستجوى بينايى در اين زمينه همخوانى داشت. بر اين اساس راحتى نسبى جستجوى خصايص و دشوارى نسبى جستجوى تركيبى مورد تأييد قرار گرفته است (YT). در نظريه مشابهت نيز تأكيد بر مشابهت هدف و محركهاى مزاحم است، به طورى كه با افزايش مشابهت بين آن دو عامل رديابى محرك هدف دشوارتر مىشود (س廿). تبيينهاى روانشناختى مختلفى براى رفتارهاى يرخطر

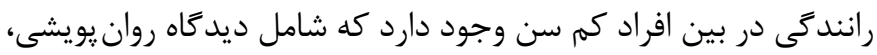
ديدگًاه شناختى و رويكرد انگيزش انسانى است (YF). در اين راستا نظريات مربوط به قضاوت و تصميهى گيرى، در زمينه عوامل اقتصادى و

روانشناختى جنين رفتارهايى مورد بررسى قرار گرفتهاند (هـ). نتايج نشان داد كه سن با تعداد تصادفهاى كل رابطهاى نداشت. اما، رابطه منفى و معنادارى بين سن و ميزان تخلفات خودگزارشى وجود داشت، كه نشاندهنده كاهش ميزان تخلفات همراه با افزايش سن است. به نظر مىرسد افراد مسنتر محافظهكارتر بوده و هيجانطلبى كمترى در رانندگى دارند. اين نتايج با يافتههاى Cestac و همكاران همخوانى داشت. آنها نشان دادند كه ميزان بالاى هيجان خواهى در جوانان مى تواند منجر به افزايش برخى تخلفات رانندگى مانند سرعت زياد شود (צr). (- مب). تعداد كل تصادفها با تخلفات خودگزارشى، رابطه مثبت و معنادار بالايى داشت. علاوه بر اين ميزان تصادفها و تخلفات خودگزارشى با ميزان شدت اختلال كم توجهى_بيشفعالى فرد رابطه مثبت و معنادارى داشت، كه نشاندهنده عدم كنترل كافى به شرايط و رفتار در رييوستار بالاى اختلال كمتوجهى_بيشفعالى است. تحقيقات نشان دادهاند كه رفتارهاى گرخطر نشانهاى از افراد دجار اختلال كمتوجهـىبيشفعالى 
شرايط واقعى بايستى مدنظر قرار گيرد. علاوه براين پيوستار اختلال كمتوجهمىبيشفعالى به صورت خودگزارشى به دست آمده است كه در برخى موارد تفاوتهايى با شرايط بررسى بالينى نشان داده است. در نهايت بايد عنوان كرد كه اگرجه يروهش حاضر از لحاظ توصيفى و همبستخى روابط بين متغيرها را بررسى كرد، بايستى مدنظر داشت كه

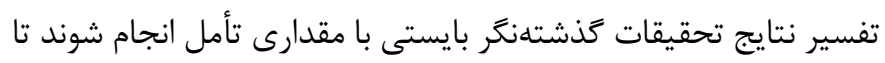
نتيجه گيرى علت و معلولى صورت نخيرد.

\section{نتيجه كيرى}

با افزايش سن ميزان تخلفات كاهش مىيابد. رابطه مثبت بين داشتن اختلال كمتوجهى_بيشفعالى با تعداد كل تصادفها و تخلفات خودَزارشى، نشاندهنده توانايى ناكافى در توجه و تمركز، كنترل كم به شرايط و رفتارهاى تكانشى است كه مىتواند منجر به اين رابطه شوند. بهتر است افرادى با اين ويزگى سعى در استفاده از روشهايى براى افزايش توجه و تمركز خود در حين رانندگى داشته باشند و يا سازمان هاى مربوطه، جنين امكاناتى را فراهم سازند. همجنين با كاهش سن و قابليتهاى بالاى جستجوى بينايى افراد، ميزان تخلفات آنها

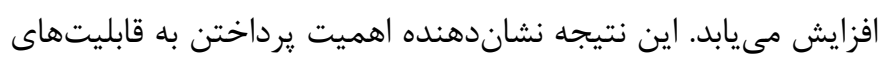
توجه و جستجوى بينايى در افرادى با سن كم را نشان مى دهد.

\section{تشكر و قدردانى}

مقاله حاضر برگرفته از طرح يزوهشى مصوب مركز تحقيقات

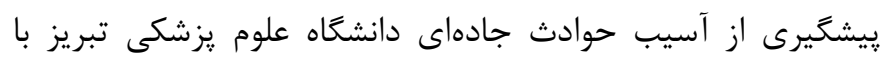
شماره VY V V • / / د/ ه است. بدين وسيله از همه همكاران آن مركز و شركت كنند كان مطالعه حاضر كمال سياس و قدردانى را داريم.

\section{References}

1. Falahzadeh H. Epidemiology of accidents in Yazd province in 2004. Journal of Legal Medicine. 2006;3(12):158-161. (Persian)

2. Salari AA, Aghili A, Piraieh Hadad F. Demographic study of traumatic patients due to accidents in Yazd. Journal of Shahid Sadoughi University of Medical Sciences. 2002;10(3):3-15. (Persian)

3. Matsubayashi K, Yamad Y, Iyoda M, Koike S, Kawasaki T, Tokuda M. Development of rear pre-crash safety system for rear-end collisions. In 20th International Technical Conference
كنند. توضيحات بيان شده نشان خصيصه و سادهترين تكليف تركيب توانستند بهترين زيشبينى كننده از ميان ويزگى هاى بينايى باشند. همان طور كه از ميانگين نمرات نيز برآورد مىشود، اين دو متغير زمان واكنش نزديك به هم داشتند. به نظر مىرسد تكاليف بسيار ساده و يا بسيار دشوار قابليت پيشبينى متغير ملاك را نداشتهاند. نتايج اين يزوهش با نتايج مؤمنى و حيدرى همخوانى داشت. آنها نيز نشان دادند كه هيجان خواهى به عنوان يك خصيصه شخصيتى در افراد حدود 19 درصد از تغييرات واريانس رفتارهاى يرخطر را در رانندكان

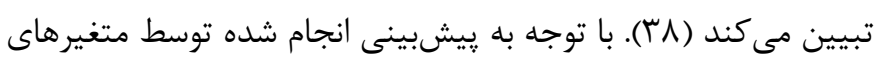
يزوهش براى ميزان تخلفات كزارش شده مىتوان موارد زير را به عنوان تيشنهاد مطرح كرد: براى ارائه گواهىنامه رانندگى ارزيابىهاى دقيقتر روانشناختى و متعاقب آن برنامههاى آموزشى جهت استفاده از روش هاى

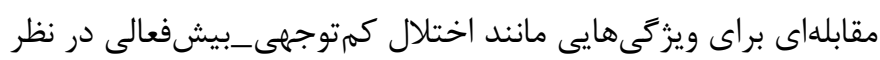
كَرفته شود. علاوه بر اين قابليت جستجوى بينايى افراد با استفاده از

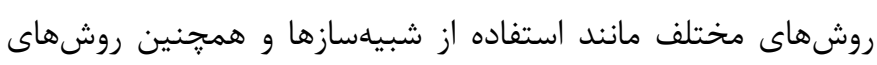
غيرمستقيهم مانند آموزشهاى حركتى و فعاليت بدنى كه در آنها قابليت جستجوى بينايى درگير است (مانند انواع بازىهاى رايانهاى و بازىهاى واقعى ادراك بينايى) ارائه شود. در مقابل موضوع نو بودن يزوهش و

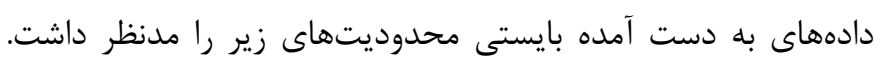
دادههاى از آزمودنىهاى سالم به دست آمدند كه قادر به شركت در مطالعه حاضر بودند و مىتوانستند با اختصاص زمان كافى و شركت در محل آزمون كل شرايط مطالعه را يشت سر بحذارند. همجنين بايستى

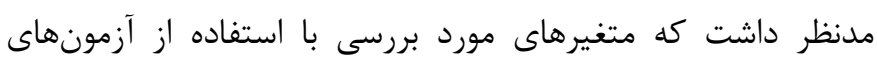

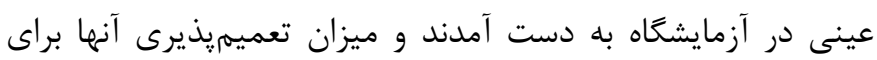

on the Enhanced Safety of Vehicles (ESV) National Highway Traffic Safety Administration 2007. 2007 Jume 18-21; Lyon, France. (No. 07-0146).

4. Zare H, Farzad V, Alipour A, Nazer M. Effectiveness of attention-shaping training in reinforcing attention in drivers with crash history. Advances in Cognitive Sciences. 2012;14(2):8797. (Persian)

5. Ericson JM, Parr SA, Beck MR, Wolshon B. Compensating for failed attention while driving. Transportation Research 
Part F: Traffic Psychology and Behaviour. 2017;45:65-74.

6. Abdoli N, Bahmani DS, Farnia V, Alikhani M, Golshani S, Holsboer-Trachsler E, et al. Among substance-abusing traffic offenders, poor sleep and poor general health predict lower driving skills but not slower reaction times. Psychology Research and Behavior Management. 2018;11:557-566.

7. Lucidi F, Mallia L, Lazuras L, Violani C. Personality and attitudes as predictors of risky driving among older drivers. Accident Analysis \& Prevention. 2014;72 318-324.

8. Mallia L, Lazuras L, Violani C, Lucidi F. Crash risk and aberrant driving behaviors among bus drivers: The role of personality and attitudes towards traffic safety. Accident Analysis \& Prevention. 2015;79:145-151.

9. Pourabdian S, Azmoon H. The relationship between trait anxiety and driving behavior with regard to self-reported Iranian accident involving drivers. International Journal of Preventive Medicine. 2013;4(10):1115-1121.

10. Beanland V, Sellbom M, Johnson AK. Personality domains and traits that predict self-reported aberrant driving behaviours in a southeastern US university sample. Accident Analysis \& Prevention. 2014;72:184-192.

11. Stephens AN, Sullman MJ. Trait predictors of aggression and crash-related behaviors across drivers from the United Kingdom and the Irish Republic. Risk Analysis. 2015;35(9):1730-1745.

12. Zhang T, Chan AH, Ba Y, Zhang W. Situational driving anger, driving performance and allocation of visual attention. Transportation Research Part F: Traffic Psychology and Behaviour. 2016;42:376-388.

13. Hilton MF, Staddon Z, Sheridan J, Whiteford HA. The impact of mental health symptoms on heavy goods vehicle drivers' performance. Accident Analysis \& Prevention. 2009;41(3):453-461.

14. Scott-Parker B, Watson B, King MJ, Hyde MK. A further exploration of sensation seeking propensity, reward sensitivity, depression, anxiety, and the risky behaviour of young novice drivers in a structural equation model. Accident Analysis \&
Prevention. 2013;50:465-471.

15. Abdoli N, Farnia V, Delavar A, Dortaj F, Esmaeili A, Farrokhi $\mathrm{N}$, et al. Mental health status, aggression, and poor driving distinguish traffic offenders from non-offenders but health status predicts driving behavior in both groups. Neuropsychiatric Disease and Treatment. 2015a;11:2063-2070.

16. Abdoli N, Farnia V, Delavar A, Esmaeili A, Dortaj F, Farrokhi N, et al. Poor mental health status and aggression are associated with poor driving behavior among male traffic offenders. Neuropsychiatric Disease and Treatment. 2015b;11:2071-2078.

17. Pauzié A. Evaluating driver mental workload using the driving activity load index (DALI). In Proceedings of European Conference on Human Interface Design for Intelligent Transport Systems. 2008 April 3-4; Lyon, France. pp. 67-77. 18. Sagberg F, Bjørnskau T. Hazard perception and driving experience among novice drivers. Accident Analysis \& Prevention. 2006;38(2):407-414.

19. Larsen L, Kines P. Multidisciplinary in-depth investigations of head-on and left-turn road collisions. Accident Analysis \& Prevention. 2002;34(3):367-380.

20. Wolfe JM. Guided search 4.0: Current progress with a model of visual search. In: Gray W, editor. Integrated models of cognitive systems. Oxford:Oxford University Press;2007. pp. 99-119. 21. Chan LK, Hayward WG. Feature integration theory revisited: Dissociating feature detection and attentional guidance in visual search. Journal of Experimental Psychology: Human Perception and Performance. 2009;35(1):119-132.

22. Arthur Jr W, Doverspike D. Locus of control and auditory selective attention as predictors of driving accident involvement: A comparative longitudinal investigation. Journal of Safety Research. 1992;23(2):73-80.

23. Moss SA, Triggs T. Attention switching time: A comparison between young and experienced drivers. In: Noy IY. Ergonomics and safety of intelligent driver interfaces: Human factors in transportation. Mahwah, NJ:Lawrence Erlbaum Associates Publishers;1997. pp. 381-392. 
24. Sternberg RJ. Cognitive psychology. 4th ed. Boston:Cengage Learning;2006.

25. Gershon P, Ben-Asher N, Shinar D. Attention and search conspicuity of motorcycles as a function of their visual context. Accident Analysis \& Prevention. 2012;44(1):97-103.

26. Geden M, Staicu AM, Feng J. The impacts of perceptual load and driving duration on mind wandering in driving. Transportation Research Part F: Traffic Psychology and Behaviour. 2018;57:75-83.

27. Underwood G, Chapman P, Brocklehurst N, Underwood J, Crundall D. Visual attention while driving: Sequences of eye fixations made by experienced and novice drivers. Ergonomics. 2003;46(6):629-646.

28. Davids K, Williams AM, Williams JG. Visual perception and action in sport. Abingdon:Routledge;2005.

29. Fifić M, Townsend JT, Eidels A. Studying visual search using systems factorial methodology with target-distractor similarity as the factor. Perception \& Psychophysics. 2008;70(4):583-603.

30. Adler LA, Kessler RC, Spencer T. Adult ADHD self-report scale-v1.1 (ASRS-v1.1) Symptom checklist. New York:World Health Organization;2003.

31. Jahangard L, Haghighi M, Bajoghli H, Holsboer-Trachsler E, Brand S. Among a sample of Iranian students, adult attention deficit hyperactivity disorder (ADHD) is related to childhood ADHD, but not to age, gender, socio-economic status or birth order-an exploratory study. Pharmacopsychiatry.
2013;46:A99.

32. Quinlan PT. Visual feature integration theory: Past, present, and future. Psychological Bulletin. 2003;129(5):643-673.

33. Bundesen C, Habekost T, Kyllingsbæk S. A neural theory of visual attention: Bridging cognition and neurophysiology. Psychological Review. 2005;112(2):291-328.

34. Kusev P, Purser H, Heilman R, Cooke AJ, Van Schaik P, Baranova $\mathrm{V}$, et al. Understanding risky behavior: the influence of cognitive, emotional and hormonal factors on decision-making under risk. Frontiers in Psychology. 2017;8:102.

35. Amiri S, Sadeghi-Bazargani H, Nazari S, Ranjbar F, Abdi S. Attention deficit/hyperactivity disorder and risk of injuries: A systematic review and meta-analysis. Journal of Injury and Violence Research. 2017;9(2):95-105.

36. Cestac J, Paran F, Delhomme P. Young drivers' sensation seeking, subjective norms, and perceived behavioral control and their roles in predicting speeding intention: How risk-taking motivations evolve with gender and driving experience. Safety Science. 2011;49(3):424-432.

37. Jerome L, Segal A, Habinski L. What we know about ADHD and driving risk: A literature review, meta-analysis and critique. Journal of the Canadian Academy of Child and Adolescent Psychiatry. 2006;15(3):105-125.

38. Momeni E, Heidari HR. Predicting high-risk behaviors regarding the role of excitement management among drivers in Tehran. Motaleat Pazhoheshi Rahvar. 2016;5(18):11-35. (Persian) 